Article

\title{
Chemical Profiling of Polyphenolics in Eucalyptus globulus and Evaluation of Its Hepato-Renal Protective Potential Against Cyclophosphamide Induced Toxicity in Mice
}

\author{
Mosad A. Ghareeb ${ }^{1, *(\mathbb{D}}$, Mansour Sobeh ${ }^{2,3}{ }^{(}$, Walaa H. El-Maadawy ${ }^{4}$, Hala Sh. Mohammed ${ }^{5}$, \\ Heba Khalil ${ }^{6}$, Sanaa Botros ${ }^{4}$ and Michael Wink ${ }^{2, *(D)}$ \\ 1 Medicinal Chemistry Department, Theodor Bilharz Research Institute, Kornaish El Nile, Warrak El-Hadar, \\ Imbaba (P.O. 30), Giza 12411, Egypt \\ 2 Institute of Pharmacy and Molecular Biotechnology, Heidelberg University, 44883-2462 Heidelberg, \\ Germany; sobeh@uni-heidelberg.de \\ 3 AgroBioSciences Research Division, Mohammed VI Polytechnic University, Lot 660-Hay MoulayRachid, \\ 43150 Ben-Guerir, Morocco \\ 4 Pharmacology Department, Theodor Bilharz Research Institute, Kornaish El Nile, Warrak El-Hadar, \\ Imbaba (P.O. 30), Giza 12411, Egypt; w.elmadawy@tbri.gov.eg (W.H.E.-M.); s.botros@tbri.gov.eg (S.B.) \\ 5 Department of Pharmacognosy, Faculty of Pharmacy (Girls), Al-Azhar University, Cairo 11311, Egypt; \\ halash1977@hotmail.com \\ 6 Pathology Department, Theodor Bilharz Research Institute, Kornaish El Nile, Warrak El-Hadar, \\ Imbaba (P.O. 30), Giza 12411, Egypt; Seif200731@gmail.com \\ * Correspondence: m.ghareeb@tbri.gov.eg (M.A.G.); wink@uni-heidelberg.de (M.W.); \\ Tel.: +20-2-010-1234-6834 (M.A.G.); +49-(0)6221-54-4880 (M.W.)
}

Received: 3 July 2019; Accepted: 19 August 2019; Published: 19 September 2019

\begin{abstract}
Cyclophosphamide $(\mathrm{CP})$ is a potent anti-neoplastic and immunosuppressive agent; however, it causes multi-organ toxicity. We elucidated the protective activities of Eucalyptus globulus (EG) leaf extract against CP-induced hepato-renal toxicity. Mice were treated with EG for 15 days plus CP on day 12 and 13 of the experiment. Using HPLC-DAD-ESI-MS/MS, 26 secondary metabolites were identified in EG leaf extract. Out of them, 4 polyphenolic compounds were isolated: (1) 4-(O- $\beta$-D-xylopyranosyloxy)-3,5-di-hydroxy-benzoic acid, (2) 4-(O- $\alpha-\mathrm{L}-$ rhamnopyranosyloxy)-3,5-di-hydroxy-benzoic acid, (3) gallic acid, and (4) methyl gallate. Effects of EG extract on biochemical parameters, gene expression, and immune-histopathological changes were assessed in comparison to mesna positive control. Results showed that EG improved CP-increased serum ALT, AST, creatinine, and blood urea nitrogen levels. The hepatic and renal tissue levels of MDA, nitric oxide, protein carbonyl, TNF- $\alpha$, IL-6, and immunohistochemical expression of nuclear factor kappa-B (NF-kB) and caspase-3 were reduced. Also, hepatic and renal GSH contents, and nuclear factor E2-related factor 2 (NRf2)/ hemoxygenase-1 (HO-1) signaling levels were increased. Histopathological findings supported our findings where hepatic and renal architecture were almost restored. Results revealed the protective effects of EG against CP-induced hepato-renal toxicity. These effects may be related to EG antioxidant, anti-inflammatory, and anti-apoptotic properties coupled with activation of Nrf2/HO-1 signaling.
\end{abstract}

Keywords: Eucalyptus globulus; polyphenolics; cyclophosphamide; hepatotoxicity; nephrotoxicity; antioxidant; anti-inflammatory; Nrf2/HO-1 signaling 


\section{Introduction}

Cyclophosphamide (CP) is prescribed in treating different types of neoplasms as well as an immunosuppressive drug in autoimmune diseases and organ transplantation [1,2]. Despite its chemotherapeutic efficacy and cost effectiveness, $\mathrm{CP}$ has a narrow therapeutic index and may be responsible for severe toxicity of vital organs [3,4]. Toxicity to liver and kidney are considered the two major ones, being the key organs responsible for $\mathrm{CP}$ metabolism and excretion, respectively $[5,6]$. $\mathrm{CP}$ is a prodrug that is metabolized within hepatocytes to generate two reactive metabolites, phosphoramide mustard and acrolein [7]. Phosphoramide mustard possesses antineoplastic activity, while acrolein is reported to be responsible for the $\mathrm{CP}$-induced cytotoxic effects $[8,9]$. Acrolein initiates oxidative stress via the production of reactive oxygen species (ROS) causing the depletion of cellular defense mechanisms, induction of lipid peroxidation [10], nucleic acid damage and mutation [11]. The overproduction of ROS also induces several signaling molecules including nuclear factor kappa-B (NF-kB), which regulates the activation of different pro-inflammatory cytokines including interleukin (IL)-6, IL-1 $\beta$ and tumor necrosis factor (TNF)- $\alpha$ [12]. Moreover, $\mathrm{CP}$ is reported to down- regulate the stress sensor transcription factor nuclear factor erythroid 2-related factor 2 (Nrf2); one of the main defensive mechanisms against stress induced injuries $[13,14]$.

$\mathrm{CP}$ is commonly administered with 2-mercaptoethane sulphonic acid (mesna); an adjuvant chemotherapeutic treatment regimen to counteract the prevalence of hemorrhagic cystitis and hematuria caused by the toxic metabolite acrolein [15]. However, the recurrence of hemorrhagic cystitis was reported with mesna [16] along with ineffectiveness in prevention of other reported CP-induced adverse drug reactions [15].

Because no adjuvant regimen is reported to offer protection to the healthy organs and tissues against $\mathrm{CP}$ toxicities without compromising its chemotherapeutic efficacy, enhancement of the antioxidant defense system to avert and/or reduce the adverse effects of $\mathrm{CP}$ and its reactive metabolites has been suggested [17]. Plant derived antioxidants preparations showed promising synergistic efficiency when co-administered with chemotherapeutic drugs mainly through their free radical scavenging and anti-inflammatory activities $[18,19]$. Natural antioxidants can enhance the current chemotherapeutic strategies not only by guarding against the adverse effects of chemotherapy but stimulating the host immune status as well [20].

Eucalyptus globulus Labill. (Myrtaceae) (EG) is an evergreen tree that is cultivated worldwide [21]. The leaf extract of EG exerts antimicrobial, antibacterial, anti-inflammatory, antioxidant, antihelmintic, and antiviral activities [22]. Moreover, previous studies reported that Eucalyptus extracts exhibited potent cytotoxic effects in various cell lines $[23,24]$ and promising antitumor activity against Ehrlich ascites carcinoma in mice $[25,26]$. These properties could be related to the abundance of phenolic compounds in the extract such as caffeic acids, quinic, luteolin, dihydroxyphenylacetic, and hydrolysable tannins $[27,28]$.

To the best of our knowledge, no previous study has investigated the hepatic and renal protective roles of EG against CP-intoxication. This study aims to identify and characterize the chemical profile of E. globulus (EG) and also investigate its protective role against CP-induced hepatic and renal toxicities in comparison to the adjuvant drug "mesna" by investigating the related mechanisms of action.

\section{Material and Methods}

\subsection{Drugs, Reagents and Instrumentations}

$\mathrm{CP}\left(\right.$ Endoxan ${ }^{\circledR}$ ) and mesna (Urometixan ${ }^{\circledR}$ ) were purchased from Baxter Oncology GMBH, Halle, Germany. Dimethyl sulfoxide (DMSO) and phosphate buffered saline solution (PBS) were purchased from Sigma-Aldrich Chemical Co., MO, USA and Lonza Bio-products, Verviers, Belgium, respectively. All other solvents and reagents were of the highest grade commercially available. The ${ }^{1} \mathrm{H}$ and ${ }^{13} \mathrm{C}-\mathrm{NMR}$ experiments were carried out using a BRUKER $400 \mathrm{MHz}$ NMR spectrometer and samples were dissolved in deuterated DMSO- $d_{6}$. 


\subsection{Preparation, Extraction and Fractionation of EG Leaf Extract as well as Chromatographic Isolation}

Fresh leaves of EG were collected from Giza Governorate in June 2016. The identification and authentication of the collected plant was established by Dr. Tearse Labib, Botany Specialist, Department of Flora and Taxonomy, El-Orman Botanical Garden, Giza, Egypt.

Air dried leaves $(1.5 \mathrm{~kg})$ were extracted three times with methanol $(4 \mathrm{~L})$ at room temperature $\left(25 \pm 2{ }^{\circ} \mathrm{C}\right)$, the extract was concentrated via a rotatory evaporator to afford $220 \mathrm{~g}$ methanol extract. It was then defatted with $1.5 \mathrm{~L}$ petroleum ether $\left(60-80{ }^{\circ} \mathrm{C}\right)$ to afford petroleum ether extract $(25 \mathrm{~g})$ and defatted methanol extract DME (175 g). DME (40 g) was subjected to polyamide (S6) column chromatography (CC) using polyamide column eluted with $\mathrm{H}_{2} \mathrm{O} / \mathrm{EtOH}$ mixtures up to pure EtOH. By using PC, UV light and spray reagents, similar fractions were collected together to obtain three main fractions. Fraction (I) was purified via Sephadex LH-20/ EtOH \& BIW (ethanol \& butanol: isopropanol: water) to obtained compounds 1 and 2. Fraction II was subjected to successive CC on Sephadex LH-20/ EtOH \& BIW to obtained compound 3. Fraction III was subjected to Sephadex LH-20 column and eluted via EtOH \& BIW to yield compound 4.

\subsection{HPLC-DAD-ESI-MS/MS Conditions}

HPLC-DAD-ESI-MS/MS was employed to investigate the chemical constituents of the extract. The LC system was Thermo Finnigan (Thermo electron Corporation, OK, USA), coupled with an LCQ Duo ion trap mass spectrometer with an ESI source (ThermoQuest). A Silica gel C18 reversed-phase column (Zorbax Eclipse XDB-C18, Rapid resolution, $4.6 \times 150 \mathrm{~mm}, 3.5 \mu \mathrm{m}$ (Agilent, CA, USA) was used for the separation process. Water with a gradient increase from $5 \%$ to $50 \%$ of acetonitrile (ACN) (with $1 \%$ formic acid each in the positive mode) was applied in $60 \mathrm{~min}$, with a flow rate $1 \mathrm{~mL} / \mathrm{min}$, and then increased to $90 \%$ ACN in the next $30 \mathrm{~min}$. The samples were injected automatically using auto sampler surveyor ThermoQuest. The instrument was controlled by Xcalibur software (Thermo Fisher Scientific Inc., OK, USA). The MS operating conditions were applied in the negative ion mode, as previously described by us [29]. The ions were detected in a full scan mode and mass range of 50-2000 m/z.

\subsection{Animals}

Adult male Swiss albino mice weighing between $25 \pm 5 \mathrm{~g}$ (purchased from the Schistosome Biology Supply Center, Theodor Bilharz Research Institute, Giza, Egypt) were used. Mice were kept in the animal house facility of the institute in standard polypropylene cages at $25 \pm 2{ }^{\circ} \mathrm{C}$ temperature with $50-60 \%$ relative humidity, $12 \mathrm{~h}$ light-dark cycles with free access to ad libitum food and water. The study protocol was approved by the Research Ethics Committee of Theodor Bilharz Research Institute (PT: 19/2/467). All procedures were conducted in accordance with the guidelines of the National Institutes of Health (NIH, 1996) and its amendments for the care and use of laboratory animals.

\subsection{Experimental Design}

Mice were randomly allocated into five groups each of six animals. Group 1 (control): Received vehicle for EG (0.5\% DMSO in PBS solution) for 15 consecutive days; Group 2 (CP): Received CP in PBS ( $200 \mathrm{mg} / \mathrm{kg}$, [30] on day 12 and 13 of the experiment, Groups 3 (CP + mesna): Received the positive control mesna (40 mg/kg, [31] $1 \mathrm{~h}$ before and $4 \mathrm{~h}$ after each CP application, Groups 4 and 5 (CP + EG): Received EG in doses of 50 and $100 \mathrm{mg} / \mathrm{kg}$ [25,26], respectively once daily for 15 days along with CP (on day 12 and 13). All treatments were administered intraperitoneally (i.p.).

After the end of treatments mice were killed under anesthesia. Blood, kidney, and liver samples were collected. Sera were separated by centrifugation and stored at $-80^{\circ} \mathrm{C}$ until analysis. The livers and kidneys were washed in cold PBS; sections of livers and kidneys were fixed in $10 \%$ neutral buffered formalin for histopathological and immunohistochemical examinations. The remaining tissue samples were homogenized $(10 \% w / v)$ in cold PBS for biochemical analyses. 


\subsection{Determination of Liver and Kidney Toxicity Indices}

Serum levels of alanine aminotransferase (ALT), aspartate aminotransferase (AST), creatinine, and blood urea nitrogen (BUN) were spectrophotometrically determined using commercially available kits (Biodiagnostics, Cairo, Egypt).

\subsection{Determination of Oxidative/Nitrosative Stress Markers and Protein Carbonyl in Liver and Kidney Tissues}

The supernatants of homogenized liver and kidney samples were used for determination of reduced glutathione (GSH) and lipid peroxidation (MDA) levels according to Ellman, 1957 [32] and Ohkawa et al., 1979 [33], respectively. The protein carbonyl (PC) (OxiSelect Cell Biolabs, CA, USA) and nitric oxide (NO) levels (Biodiagnostics, Cairo, Egypt) were measured using commercially available kits and the amount of total protein was determined by BCA protein assay kit (Thermo Fischer Scientific, IL, USA).

\subsection{Determination of Nrf2/HO-1 Pathway Activation in Liver and Kidney Tissues}

Gene expression levels of Nrf2 were determined using quantitative reverse transcriptase real time polymerase chain reaction (qRT-PCR). Briefly, total RNA was isolated from hepatic and kidney samples using TRIzol (Invitrogen, CA, USA), and quantified using a nanodrop. RNA samples were used for DNA synthesis using cDNA Synthesis Kit. Amplification of the cDNA was carried out by SYBR Green master mix (Applied biosystems, CA, USA). All values were normalized to the housekeeping $\beta$-actin gene. Relative expression of studied genes was calculated using the comparative threshold cycle method ( $2^{-\Delta \Delta C t}$ method).

The sequences of PCR primer pairs used were:

$$
\begin{gathered}
\text { Nrf2 F: TTGTAGATGACCATGAGTCGC } \\
\text { R: TGTCCTGCTGTATGCTGCTT } \\
\text { B-actin F: AGGAGTACGATGAGTCCGGC } \\
\text { R: CGCAGCTCAGTAACAGTCCG }
\end{gathered}
$$

Next, the hepatic and renal levels of heme oxygenase-1 (HO-1) were measured using the commercial ELISA kit according to the manufacturer's instructions (OxiSelect Cell Biolabs, CA, USA).

\subsection{Determination of Pro-inflammatory Markers and Caspase-3 in Liver and Kidney Tissues}

The liver and kidney pro-inflammatory markers, TNF- $\alpha$ and IL-6, were measured using the commercially available ELISA kits according to the manufacturer's instructions (OxiSelect Cell Biolabs, CA, USA) and the amount of total protein was determined by a BCA protein assay kit.

Moreover, sections on charged slides (Superfrost charged slides, Thermo Scientific, Braunschweig, Germany) from liver and kidney tissues were immunohistochemically stained with anti-NF- $\mathrm{kB}$ and anti-caspase-3 (Santa Cruz Biotechnology, CA, USA, respectively) using an Ultra Benchmark machine (Roche, Tucson, USA) and an Optiview Detection kit with haematoxlin as the counterstain. The percent of positively stained brown nuclei and cytoplasm for NF- $\mathrm{KB}$ and caspase-3, respectively, were examined in five microscopic fields (at x400 under Zeiss light microscopy, Jena, Germany).

\subsection{Histopathological Examination}

Liver and kidney tissues embedded in paraffin blocks were sectioned at $4 \mu \mathrm{m}$ thickness. Sections were stained with hematoxylin/eosin (H\&E) and blindly examined for the extent of liver and kidney damage under bright field microscope (Olympus BX53F).

\subsection{Statistical Analysis}

Data are expressed as mean \pm SEM. Statistical analysis was performed using one-way analysis of variance (ANOVA) followed by Tukey-Kramer as post hoc test for multiple comparisons (GraphPad Software, San Diego, CA, USA, version 5.03). $p<0.05$ was considered statistically significant. 


\section{Results}

\subsection{HPLC-DAD-ESI-MS-MS Annotation and Chromatographic Isolation of Polyphenolic Compounds}

In the current study, HPLC-DAD-ESI-MS/MS was used to identify the polyphenolic secondary metabolites in the methanol extract of E. globulus leaves. Based on the retention time and fragmentation pattern in the negative ion mode, 26 compounds were tentatively identified in the extract and were categorized as phenolic acids, flavonoids, and hydrolyzable tannins. The major identified compounds were gallic acid pentoside (1), gallic acid rhamnoside (2), gallic acid (3), methyl gallate (4), isorhamnetin 3-O- $\beta$-D-glucuronoside (12), galloyl cypellocarpin B (13), galloyl ester of a methylellagic acid glucoside (17), quercetin-3,4'-dimethyl ether (18), cypellocarpin C (20), dihydroquercetin (22), valoneoyl-digalloyl-glucopyranose (24), eicosanoic acid (25), and valoneic acid dilactone (26) (Supplementary data S1). The results are documented in Table 1 and Figure 1. Out of the annotated compounds, 4 compounds were isolated and characterized based on their NMR data as (1) 4-(O- $\beta$-D-xylopyranosyloxy)-3,5-di-hydroxy-benzoic acid, (2) 4-(O- $\alpha$-Lrhamnopyranosyloxy)-3,5-di-hydroxy-benzoic acid, (3) 3,4,5-trihydroxybenzoic acid (gallic acid), and (4) methyl 3,4,5-trihydroxybenzoate (methyl gallate) (Figure 2) (Supplementary data S2).

Table 1. Phenolic compounds tentatively identified in the methanol extract of E. globulus (EG) leaves by HPLC-DAD-ESI-MS/MS.

\begin{tabular}{|c|c|c|c|c|}
\hline No. & $R_{t}$ & {$[\mathbf{M}-\mathbf{H}]^{-}$} & Major Product Ions $(\mathrm{m} / \mathrm{z})$ & Tentative Identified Compounds * \\
\hline 1 & 1.41 & 301 & $169,125^{c}$ & Gallic acid pentoside ${ }^{a, b}$ \\
\hline 2 & 2.54 & 315 & 169,125 & Gallic acid rhamnoside $a, b$ \\
\hline 3 & 6.30 & 169 & 125 & Gallic acid $^{\mathrm{a}, \mathrm{b}}$ \\
\hline 4 & 6.69 & 183 & $183,169,125$ & Methyl gallate ${ }^{a, b}$ \\
\hline 5 & 8.16 & 353 & 191,161 & Chlorogenic acid \\
\hline 6 & 10.46 & 267 & $251,223, \mathbf{2 2 1}, 205,203,193,97,85$ & Unidentified \\
\hline 7 & 13.55 & 537 & $313,271,211,169$ & Mallophenol B \\
\hline 8 & 15.89 & 521 & $491,359,179$ & Rosmarinic acid hexoside \\
\hline 9 & 16.29 & 483 & $331,271,211,169$ & Digalloylglucose \\
\hline 10 & 17.16 & 421 & $331,313,169,151,125$ & Benzyl-galloylglucose \\
\hline 11 & 17.50 & 481 & $463,301,271,151$ & Hexahydroxydiphenoyl-glucose \\
\hline 12 & 18.68 & 491 & $473,431, \mathbf{3 1 5}, 301,179$ & Isorhamnetin $3-O-\beta$-D-glucuronoside \\
\hline 13 & 19.64 & 689 & $537,519,211,193$ & Galloyl cypellocarpin B \\
\hline 14 & 19.82 & 939 & $769,635,617,599,465$ & Pentagalloylglucose \\
\hline 15 & 20.12 & 635 & $483,465,423,331,169$ & Trigalloylglucose \\
\hline 16 & 21.54 & 625 & $473,463,437,301,257$ & HHDP-diglucoside \\
\hline 17 & 24.91 & 629 & 477, 315, 301 & $\begin{array}{l}\text { Galloyl ester of a methylellagic acid } \\
\text { glucoside }\end{array}$ \\
\hline 18 & 25.31 & 329 & $329,314,301,300,299,285,243$ & Quercetin-3,4'-dimethyl ether \\
\hline 19 & 27.17 & 1085 & $765,633,473$ & Eucalbanin A or cornusiin B \\
\hline 20 & 28.52 & 519 & $353,335,233$ & Cypellocarpin C \\
\hline 21 & 29.61 & 1415 & $1113,933,783,633$ & Di (HHDP-galloylglucose)-pentose \\
\hline 22 & 40.34 & 303 & $301,285,259,179,125$ & Dihydroquercetin (Taxifolin) \\
\hline 23 & 41.82 & 617 & $465,343,303,169$ & Trigalloyllevoglucosan \\
\hline 24 & 53.13 & 953 & $635,301,169$ & Valoneoyl-digalloyl-glucopyranose \\
\hline 25 & 55.60 & 311 & 296, 293, 195 & Eicosanoic acid \\
\hline 26 & 56.04 & 469 & $425,423,301,169$ & Valoneic acid dilactone \\
\hline
\end{tabular}

* HPLC-DAD-ESI-MS-MS annotation of the polyphenolic compounds based on their retention time, fragmentation pattern, and via comparison of MS spectra with the reported data [34-44]. ${ }^{a}$ Compounds isolated and identified via HPLC-DAD-ESI-MS/MS during this study. ${ }^{b}$ The structural elucidation of the isolated phenolic compounds (1-4) was based on spectral and chemical analyses as well as literature [45-48]. ${ }^{\mathrm{c}}$ Bold items referred to the main aglycones fragments. 


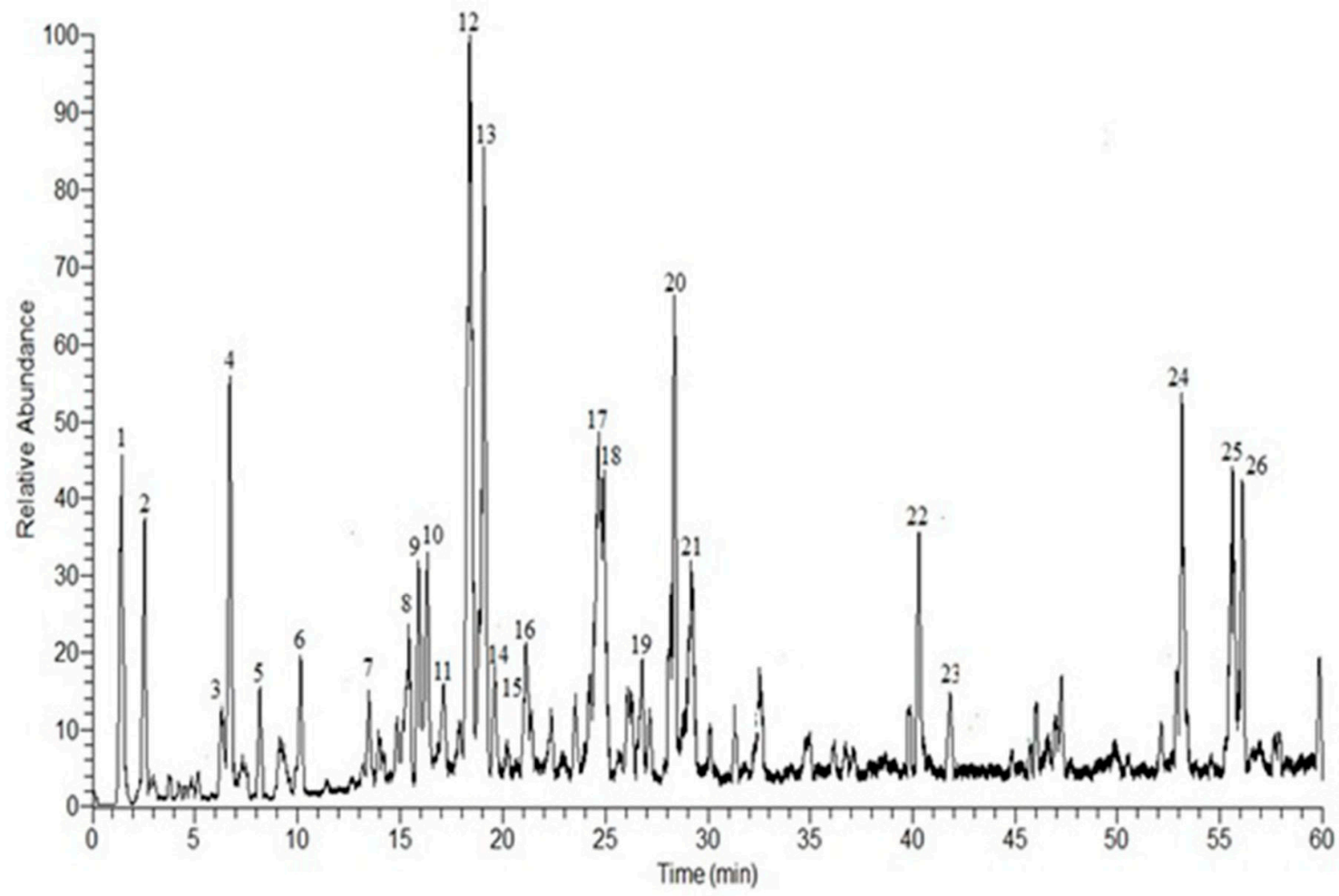

Figure 1. Negative HPLC-DAD-ESI-MS/MS profile of phenolic compounds from the methanol extract of E. globulus leaves. Peak numbers agree with those in Table 1.

\subsection{EG Pretreatment Alleviated CP Induced Liver and Kidney Damage}

$\mathrm{CP}$ caused a substantial increase in serum levels of ALT, AST, creatinine, and BUN $(3,3.6,1.9$, and 3.4 fold, respectively) when compared to normal controls. Mesna modestly reduced their levels when compared to CP treated animals. Pretreatment with EG at doses of 50 and $100 \mathrm{mg} / \mathrm{kg}$ resulted in a significant dose dependent reduction in these parameters when compared to corresponding $\mathrm{CP}$ or mesna treated mice. EG when given in a dose of $100 \mathrm{mg} / \mathrm{kg}$ normalized the levels of ALT, AST, and creatinine (Table 2).

Table 2. Protective effects of EG pretreatment on the serum markers against cyclophosphamide (CP)-induced hepato-renal toxicities in mice.

\begin{tabular}{ccccc}
\hline \multirow{2}{*}{ Animal Groups } & \multicolumn{2}{c}{ Liver Functions } & \multicolumn{2}{c}{ Kidney Functions } \\
\cline { 2 - 5 } & ALT & AST & Creatinine & BUN \\
\hline Normal Control & $23.65 \pm 0.80$ & $42.38 \pm 1.27$ & $0.26 \pm 0.02$ & $11.97 \pm 0.47$ \\
CP & $70.17 \pm 1.65^{*}$ & $152.39 \pm 1.34^{*}$ & $0.49 \pm 0.02^{*}$ & $40.40 \pm 1.71^{*}$ \\
CP + mesna & $60.11 \pm 1.60^{* \#}$ & $126.26 \pm 1.33^{* \#}$ & $0.39 \pm 0.01^{* \#}$ & $31.71 \pm 0.91^{* \#}$ \\
CP + EG (50 mg/kg) & $33.68 \pm 0.90^{* \#+}$ & $61.11 \pm 1.23^{* \#+}$ & $0.34 \pm 0.01^{* \dagger}$ & $25.68 \pm 0.65^{* \#+}$ \\
CP + EG $(100 \mathrm{mg} / \mathrm{kg})$ & $24.78 \pm 0.65^{\#+\ddagger}$ & $46.10 \pm 0.96^{\#+\ddagger}$ & $0.29 \pm 0.01^{\#+\ddagger}$ & $16.29 \pm 0.52^{* \#+}$ \\
\hline
\end{tabular}

Data are represented as mean $\pm \operatorname{SEM}(n=6) .{ }^{*} p<0.05$ vs. normal control, ${ }^{\#} p<0.05$ vs. $\mathrm{CP}^{+}{ }^{+} p<0.05$ vs. $\mathrm{CP}+$ mesna, $\ddagger p<0.05 \mathrm{vs}$. CP+EG $(50 \mathrm{mg} / \mathrm{kg})$. Statistical analysis was done using one-way ANOVA followed by Tukey's multiple comparisons test. ALT: alanine aminotransferase, AST: aspartate aminotransferase, BUN: blood urea nitrogen, CP: cyclophosphamide, EG: E. globulus. 
1. $\mathrm{R}_{\mathbf{1}}=\mathrm{H}, \mathrm{R}_{\mathbf{2}}=\mathbf{4}-(\mathrm{O}-\mathrm{B}-\mathrm{D}-\mathrm{xylopyranosyloxy})$

2. $\mathrm{R}_{1}=\mathrm{H}, \mathrm{R}_{2}=4$ - $(O$-alpha-L-rhamnopyranosyloxy $)$

3. $\mathbf{R}_{1}=\mathbf{H}, \mathbf{R}_{2}=\mathbf{H}$

4. $\mathrm{R}_{1}=\mathrm{CH}_{3}, \mathrm{R}_{2}=\mathrm{H}$<smiles>[R20]Oc1c(O)cc(C(=O)OCC)cc1O</smiles><smiles>O=C(O)c1cc(O)c(O)c(O)c1Oc1cc2c(=O)oc3c(O)c(O)cc4c(=O)oc(c1O)c2c34</smiles>

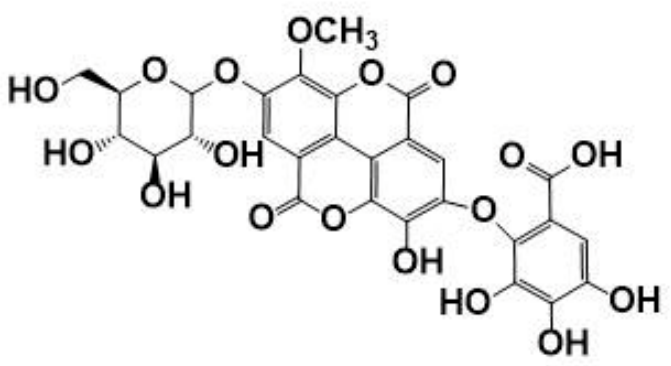

Valoneic acid dilactone

Galloyl ester of methylellagic acid glucoside<smiles>COc1cc(-c2oc3cc(O)cc(O)c3c(=O)c2O[C@@H]2O[C@H](CO)[C@@H](O)[C@H](O)[C@H]2O)ccc1O</smiles><smiles>COc1ccc(-c2oc3cc(O)cc(O)c3c(=O)c2OC)cc1O</smiles>

Isorhamnetin 3-O-beta-D-glucopyranoside

Quercetin 3,4'-dimethyl Ether<smiles>Cc1cc(=O)c2c(O)cc(O[C@@H]3O[C@H](COC(=O)C4=CCC(C(C)(C)O)CC4)[C@@H](O)[C@H](O)C3O)cc2o1</smiles><smiles>O=C1c2c(O)cc(O)cc2OC(c2ccc(O)c(O)c2)C1O</smiles>

Dihydroquercetin

Figure 2. Chemical structures of phenolic compounds isolated from Eucalyptus globulus as well as some major annotated compounds by HPLC-DAD-ESI-MS/MS.

Hepatic tissues of $\mathrm{CP}$ treated mice revealed hydropic degeneration of hepatocytes, hyperemia, congestion, dilatation of sinusoids. Minor to moderate improvement in hepatic damage was recorded in mesna and EG $(50 \mathrm{mg} / \mathrm{kg}$ ) treated mice, respectively, whereas normal hepatic architecture was recorded upon pretreatment with $100 \mathrm{mg} / \mathrm{kg}$ EG (Figure 3A). Renal tissues of CP treated mice showed degenerated renal tubules with hyaline casts, atrophy in the glomeruli with mesangeal proliferation, tubular degeneration and dilatation in bowman capsules. Pretreatment with EG in doses of 50 and $100 \mathrm{mg} / \mathrm{kg}$ revealed a dose dependent improvement in the histological changes of the glomeruli and renal tubules (Figure 3B). 
(A) Liver

(B) Kidney
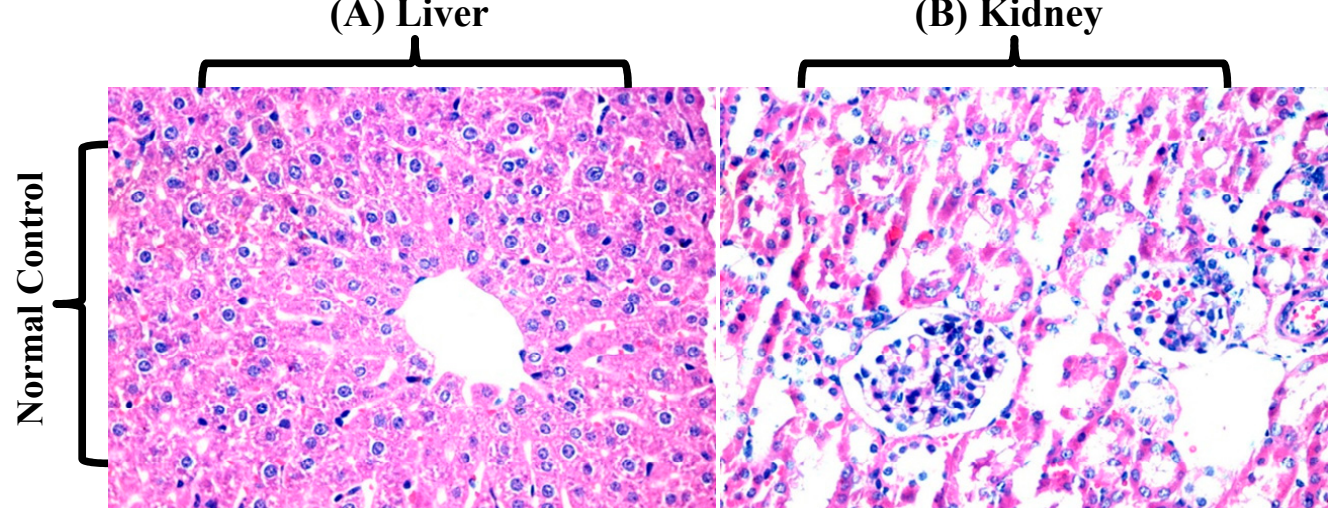

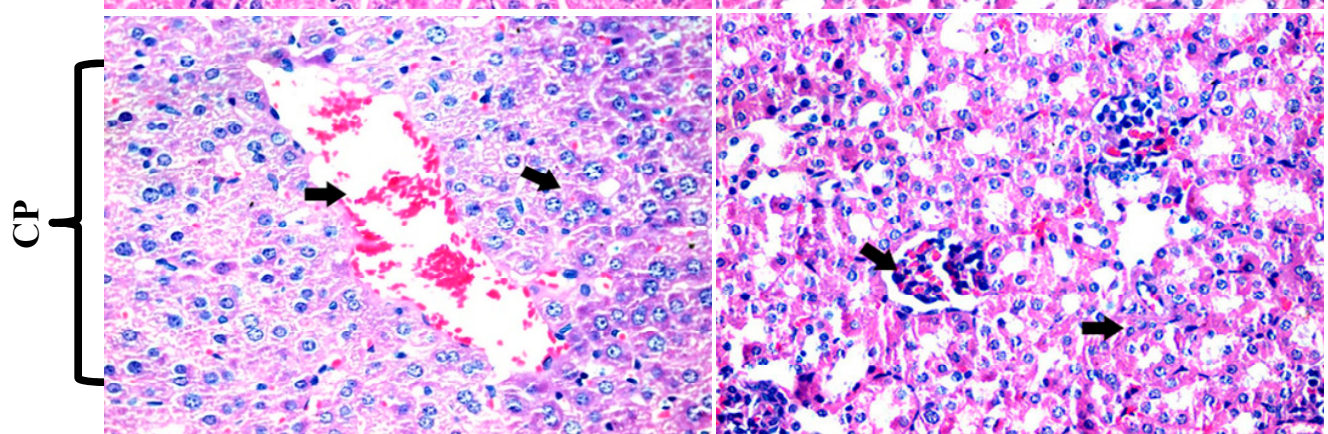
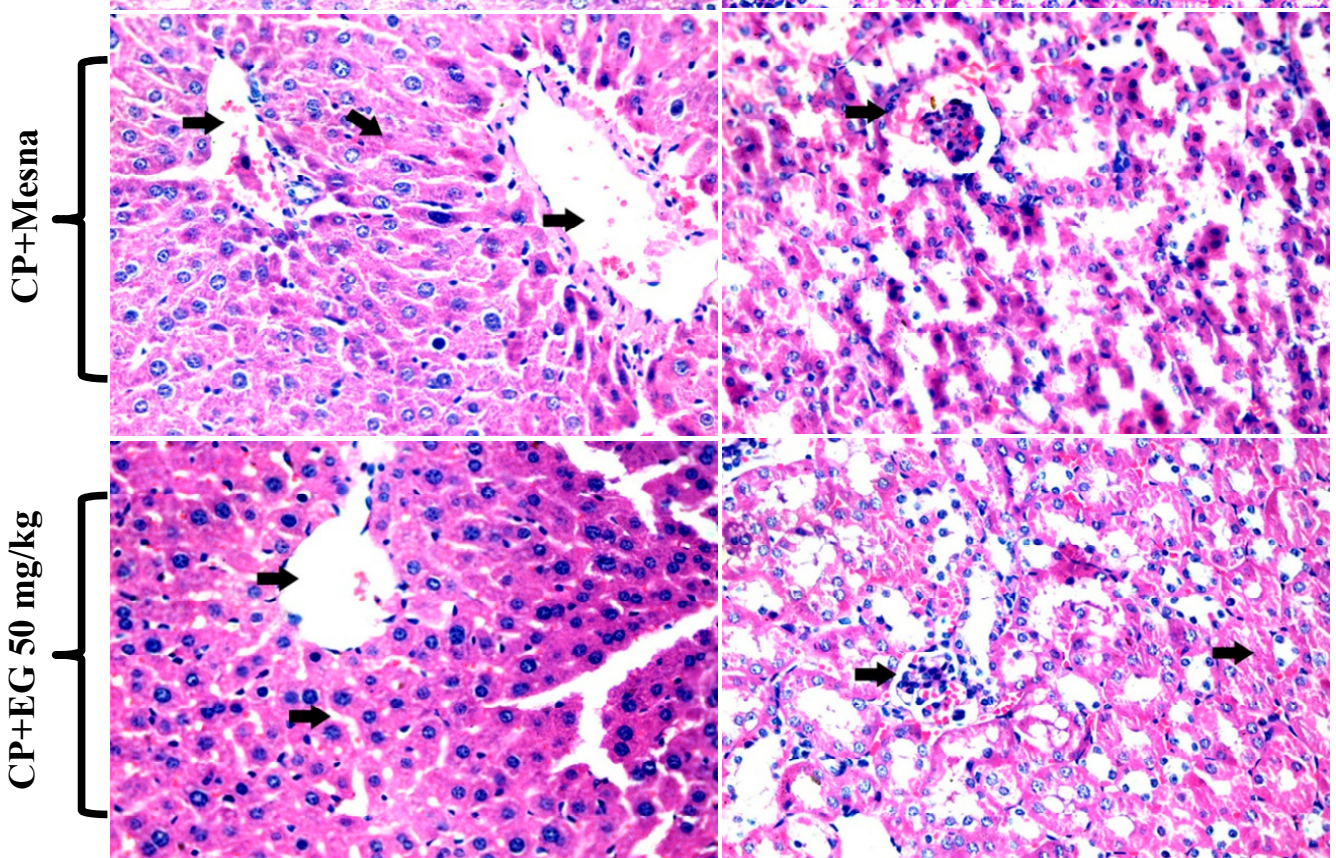

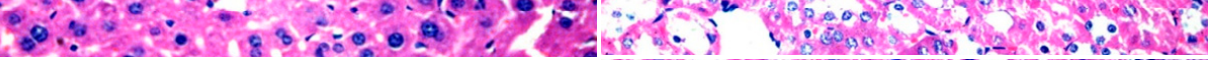

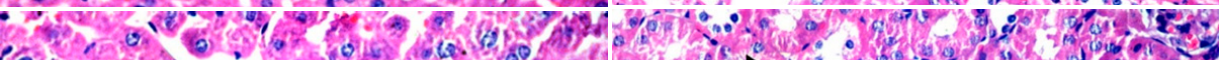

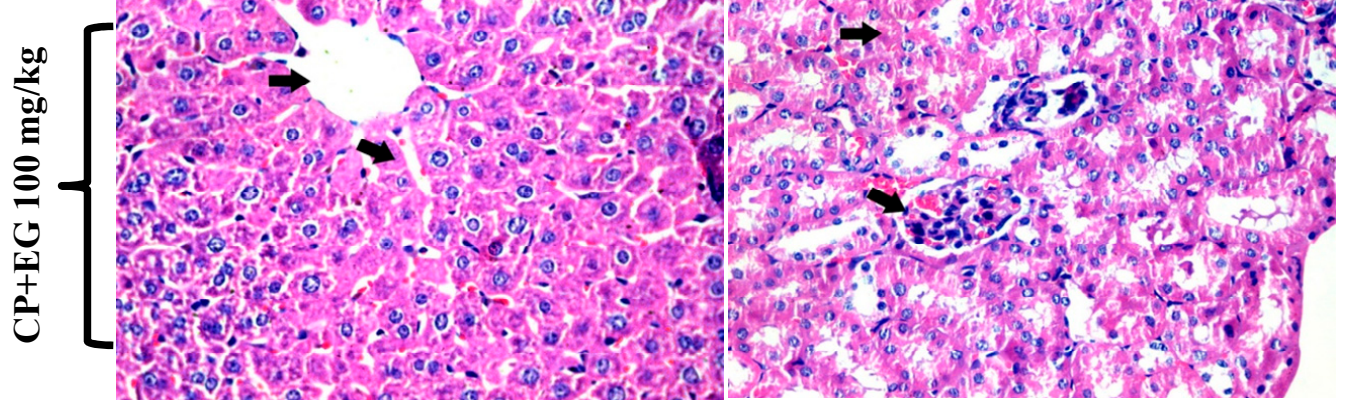

Figure 3. Photomicrographs showing the protective effects of EG pretreatment on $\mathrm{CP}$-induced damage in hepatic (A) and renal (B) tissue sections stained with H\&E $(\times 400)$. 


\subsection{EG Pretreatment Mitigated CP-induced Oxidative/Nitosative Stress and Protein Carbonylation in Liver and Kidney Tissues}

CP caused a considerable increase in the liver and kidney MDA levels (2.3- and 2.4-fold, respectively) with depletion in their GSH contents (71.7 and 67.6\%, respectively) as compared to normal controls. Mesna revealed insignificant changes in hepatic GSH content, trivial decrement in the increased MDA levels, but resulted in significant improvement in renal GSH contents (50.6\%) in comparison to CP treated mice. Compared to CP or mesna treated mice, pretreatment with $50 \mathrm{mg} / \mathrm{kg}$ EG resulted in significant drop in the hepatic and renal MDA levels with marked increase in their GSH contents. Pretreatment with $100 \mathrm{mg} / \mathrm{kg}$ EG restored their normal levels in both the hepatic and renal tissues (Figure 4A,B).
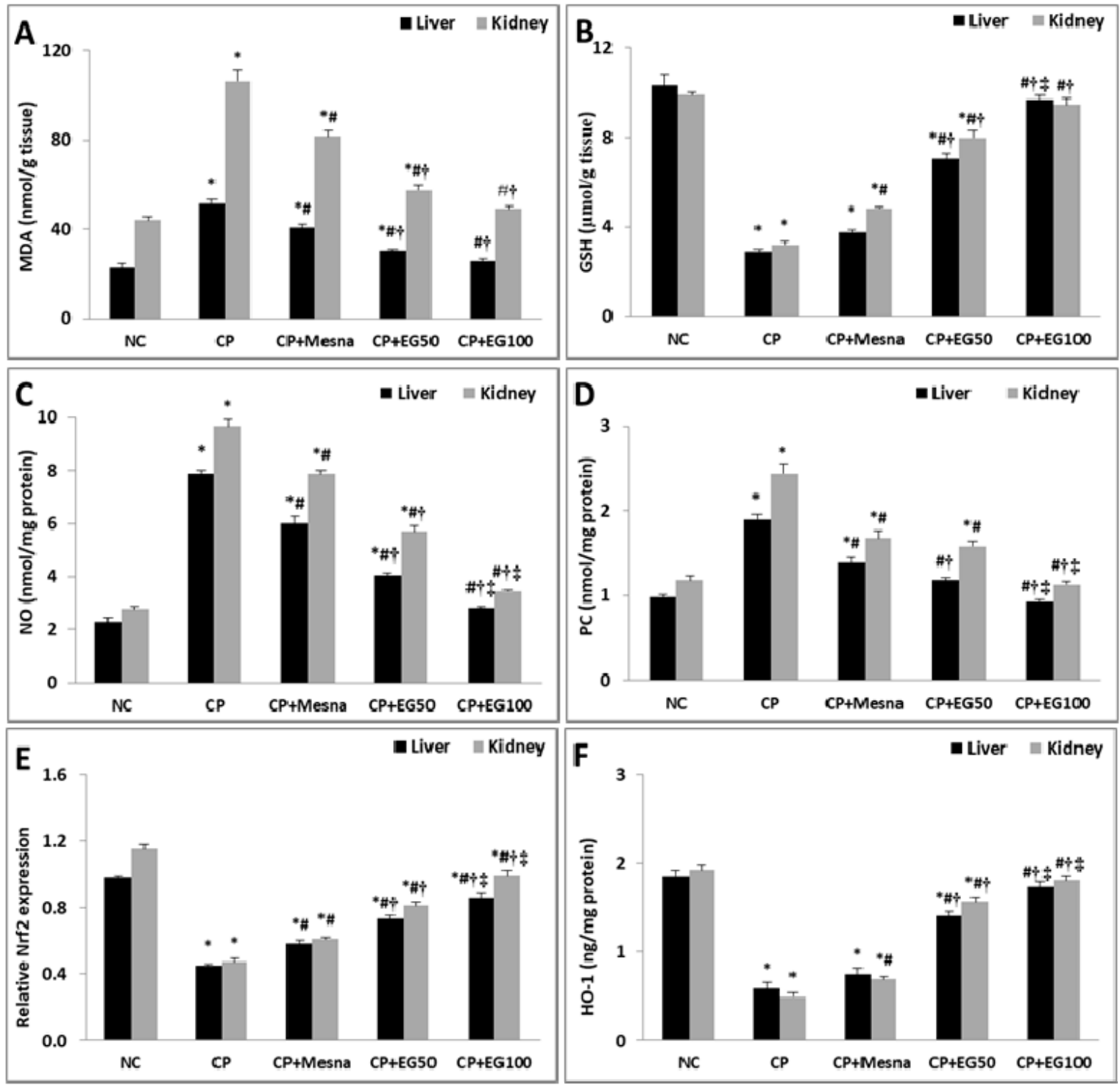

Figure 4. Effect of EG pretreatment on hepatic and renal levels of MDA (A), GSH (B), NO (C) and PC (D), on Nrf2 gene expression (E) and HO-1 levels (F) in CP-treated mice.

Compared to normal mice, CP induced a marked increase in NO and PC levels of both hepatic (3.5- and 1.9-fold, respectively) and renal (3.5- and 2-fold, respectively) tissues. Mesna showed a significant decrease in their levels in hepatic (23.8 and $26.80 \%$, respectively) and renal (18.7 and $31.2 \%$, respectively) tissues when compared to CP treated animals. Pretreatment with either 50 or $100 \mathrm{mg} / \mathrm{kg}$ EG notably alleviated the increased levels of PC and NO in the liver and kidney in a dose dependent 
way when compared to $\mathrm{CP}$ and mesna treated mice. Pretreatment with $100 \mathrm{mg} / \mathrm{kg}$ EG neutralized the increased PC and NO levels in the liver and kidney of CP treated mice (Figure 4C,D).

Data are represented as mean $\pm \operatorname{SEM}(n=6) .{ }^{*} p<0.05$ vs. normal control, ${ }^{\#} p<0.05$ vs. CP, ${ }^{\dagger} p<0.05$ vs. CP + mesna, ${ }^{\ddagger} p<0.05$ vs CP + EG (50 mg/kg). Statistical analysis was done using one-way ANOVA followed by Tukey's multiple comparisons test. MDA: malondialdehyde, GSH: reduced glutathione, NO: nitric oxide, PC: Protein carbonyl, Nrf2: nuclear factor erythroid 2-related factor 2, HO-1: heme oxygenase-1, NC: normal control, CP: cyclophosphamide, EG: E. globulus.

\subsection{EG Pretreatment Activated Nrf2/HO-1/Antioxidant Signaling in The Livers and Kidneys of CP Treated Mice}

$\mathrm{CP}$ treated mice showed a substantial drop in hepatic and renal gene expression of Nrf2 (54 and $59.1 \%$, respectively) in comparison to normal controls. Mesna demonstrated a moderate decline in hepatic $(28.9 \%)$ and renal $(29.8 \%)$ expression of Nrf2 as compared to CP treated mice. Mice treated with either 50 or $100 \mathrm{mg} / \mathrm{kg}$ EG exhibited a considerable rise in the hepatic (62.2 and 91.1\%, respectively) and renal (72.3 and 110.6\%, respectively) Nrf2 mRNA expression when compared with CP treated animals. Moreover, the enhancement in the hepatic (25.86 and $48.28 \%$, respectively) and renal (32.79 and $62.30 \%$, respectively) Nrf2 expression was more prominent when compared to mesna treated groups (Figure 4E).

The cytoprotective isoenzyme HO-1 levels were significantly reduced in hepatic $(68.7 \%)$ and renal (74.5\%) tissues of $\mathrm{CP}$ treated mice when compared to normal controls. Mesna did not reveal any significant changes in hepatic HO-1 levels whereas a significant rise of renal HO-1 levels (40.8\%) was recorded in comparison with $\mathrm{CP}$ treated groups. Mice pretreated with EG in a dose of 50 and $100 \mathrm{mg} / \mathrm{kg}$ showed a dose dependent increase in hepatic HO-1 levels when compared to either CP (2.4- and 3-fold) or mesna (1.9- and 2.3-fold) treated groups, respectively. Similarly, a dose dependent elevation in renal HO-1 levels was detected in pretreated groups with EG $(50$ and $100 \mathrm{mg} / \mathrm{kg}$ ) when compared to either CP (3.2- and 3.7-fold) or mesna (2.3- and 2.6-fold) treated groups. Moreover, pretreatment with $100 \mathrm{mg} / \mathrm{kg}$ EG normalized the reduced HO-1 levels in livers and kidneys of CP-treated mice (Figure 4F).

\subsection{EG Pretreatment Down-regulated CP-induced Inflammation in Liver and Kidney Tissues}

The levels of the pro-inflammatory cytokines, TNF- $\alpha$ and IL-6, were increased in the livers $(92.1 \%$ and $129.9 \%$ ) and kidneys ( $80.8 \%$ and $97.8 \%$ ) of CP treated mice when compared to normal controls. Mesna caused a partial reduction in both hepatic and renal levels of TNF- $\alpha$ ( $23.6 \%$ and $17 \%)$ and IL-6 $(17.7 \%$ and $28.5 \%)$ when compared to CP treated groups. Pretreatment with EG resulted in a dose dependent reduction in their hepatic and renal levels in comparison to either $\mathrm{CP}$ or mesna treated groups. Additionally, EG pretreatment in a dose of $100 \mathrm{mg} / \mathrm{kg}$ neutralized the elevated hepatic and renal levels of both cytokines (Figure 5A,B).

IHC expression of NF- $\mathrm{kB}$ revealed minimal basal levels in normal hepatic and renal tissues. However, a prominent up-regulation in its expression was detected in CP-treated liver (mainly in hepatocytes around the central vein) and kidney (identified in the renal tubules and glomeruli) tissues by 52.2 - and 60 -fold, respectively, as compared to normal controls. Mesna showed a significant reduction by $16.7 \%$ and $25 \%$, respectively, when compared to the $\mathrm{CP}$-treated group. EG pretreatment in doses of 50 and $100 \mathrm{mg} / \mathrm{kg}$ exhibited a dose dependent decline in hepatic expression of NF- $\mathrm{KB}$ in comparison to $\mathrm{CP}(54.8 \%$ and $83.4 \%$, respectively) and mesna ( $45.7 \%$ and $80 \%$, respectively) treated groups. A similar dose dependent down-regulation was observed in NF- $\mathrm{kB}$ renal expression in comparison to $\mathrm{CP}(55.6 \%$ and $77.8 \%$, respectively) and mesna ( $40.7 \%$ and $70.4 \%$, respectively) treated groups (Figure 5C,D).

Data are represented as mean $\pm \operatorname{SEM}(n=6) .{ }^{*} p<0.05$ vs. normal control, ${ }^{\#} p<0.05$ vs. $\mathrm{CP},{ }^{\dagger} p<0.05$ vs. $\mathrm{CP}+$ mesna, $\neq p<0.05 \mathrm{vs}$. CP + EG $(50 \mathrm{mg} / \mathrm{kg})$. Statistical analysis was done using one-way ANOVA followed by Tukey's multiple comparisons test. TNF- $\alpha$ : tumor necrosis- $\alpha$, IL-6: interleukin-6, NF- $\mathrm{kB}$ : nuclear factor-kappa B, NC: normal control, CP: cyclophosphamide, EG: E. globulus. 

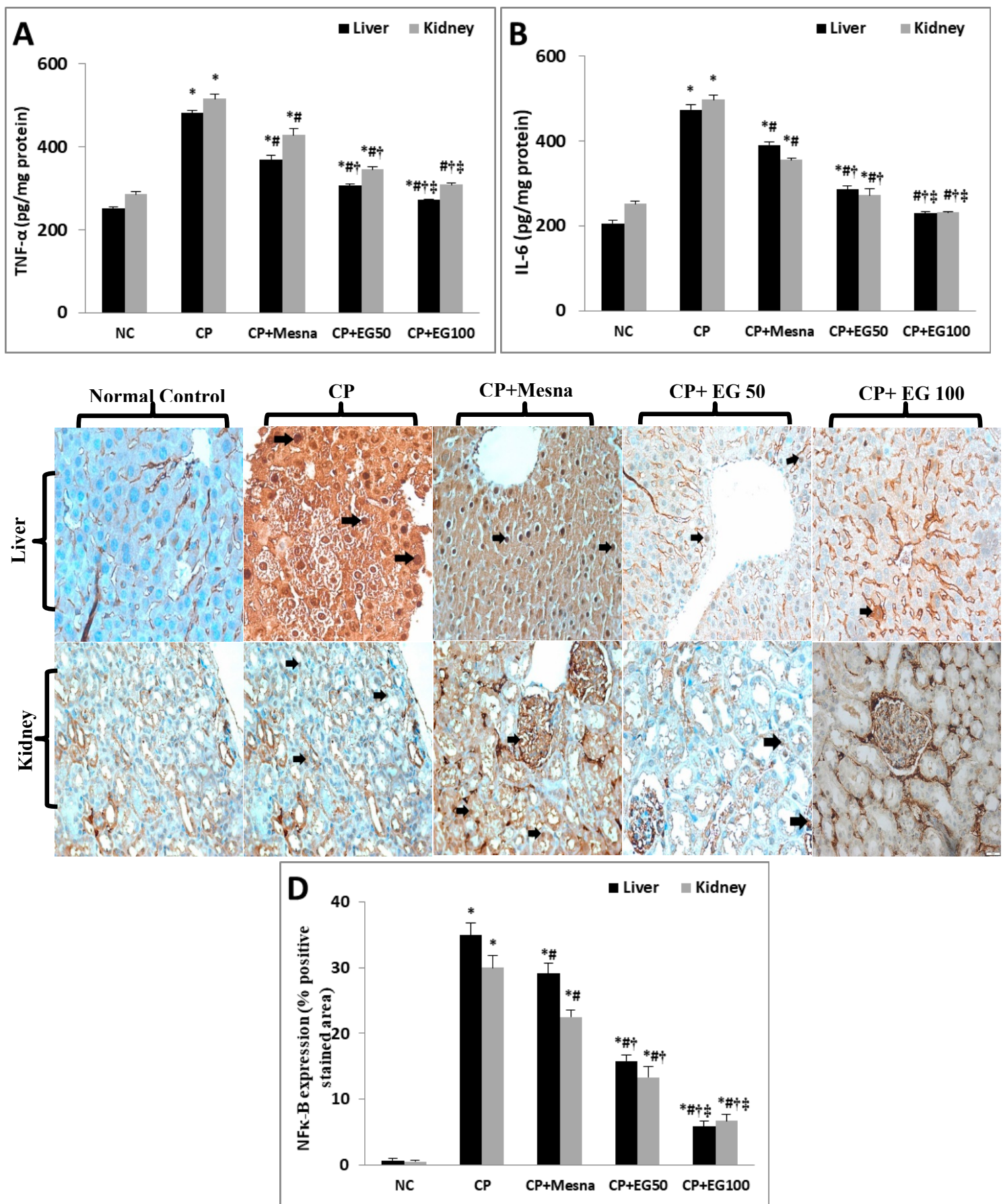

Figure 5. Effect of EG pretreatment on liver and kidney levels of pro-inflammatory markers (TNF- $\alpha$ (A), IL-6 (B)), IHC expression of NF-kB ( $\times 400$, black arrows represent localization of positively stained brown nuclei with faint ignored background staining) (C) and semi-quantitative estimation of NF- $\mathrm{B}$ positively stained nuclei in hepatic and renal tissues of CP-treated mice.

\subsection{EG Blocked CP-induced Apoptosis in the Liver and Kidney of Mice}

IHC expression of caspase-3 was markedly up-regulated in CP treated hepatic (34.2-fold) and renal tissues (43.2-fold) when compared to untreated tissues. Caspase-3 positively stained cells were observed mainly in hepatocytes around the central vein and in the renal tubules and glomeruli. Administration of mesna did not show significant changes in hepatic and renal caspase-3 expression when compared to CP-treated groups. EG pretreatment in doses of 50 and $100 \mathrm{mg} / \mathrm{kg}$ showed dose dependent reduction in hepatic expression of caspase- 3 in comparison to CP (53.7\% and $80.5 \%$, respectively) and mesna 
(48.7\% and $78.4 \%$, respectively) treated groups. Also, a dose dependent down-regulation in caspase- 3 renal expression was observed in comparison to CP (46.5\% and $69.8 \%$, respectively) and mesna (37.8\% and $64.9 \%$, respectively) treated groups (Figure 6A,B).

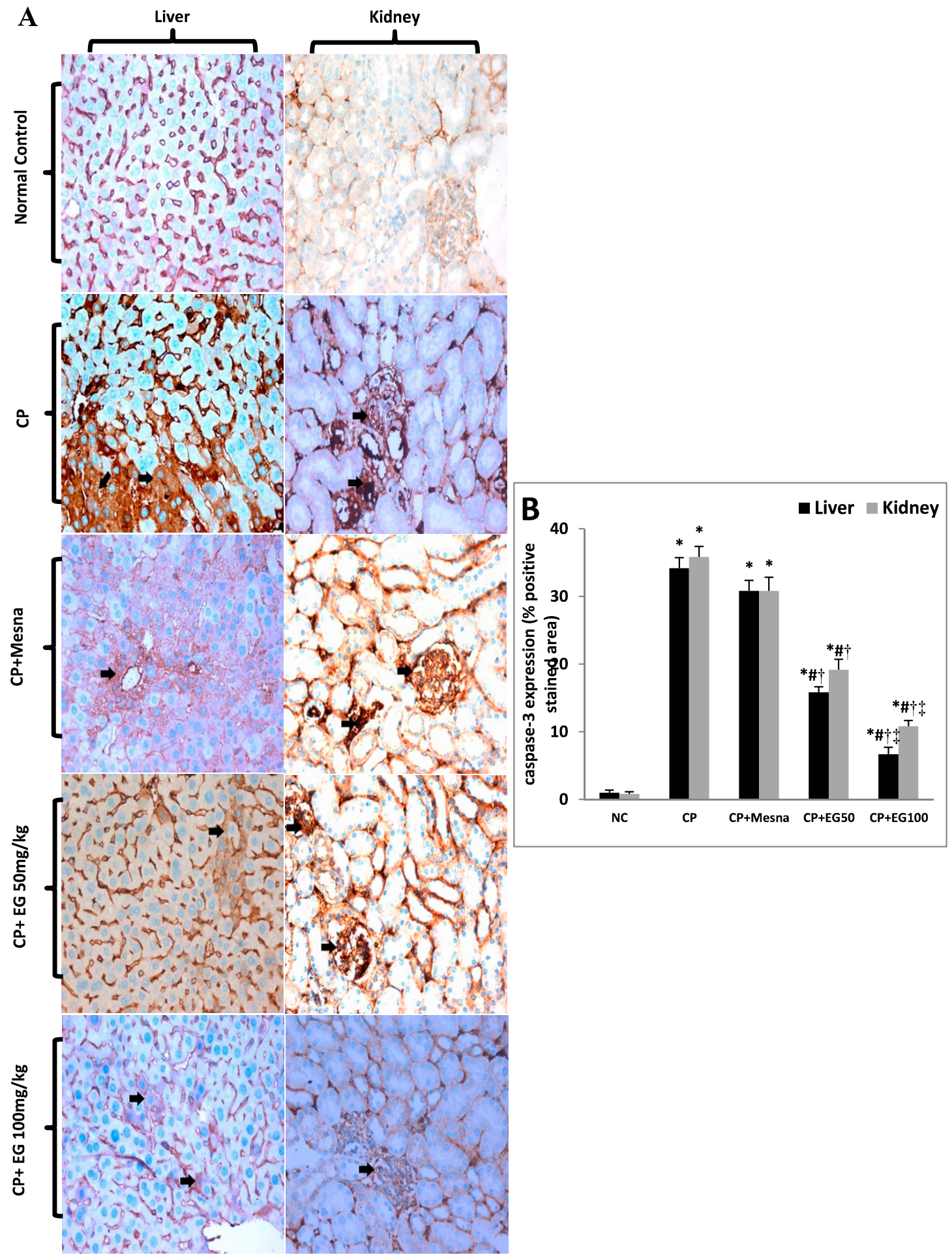

Figure 6. Effect of EG pretreatment on IHC expression of caspase-3 $(\times 400$, black arrows represent localization of positively stained brown cytoplasm with ignored cross reaction in sinusoids as appeared in normal control section) (A) and semi-quantitative estimation of caspase-3 positively stained cells in hepatic and renal tissues of CP-treated mice. 
Data are represented as mean $\pm \operatorname{SEM}(n=6) .{ }^{*} p<0.05$ vs. normal control, ${ }^{*} p<0.05$ vs. CP, ${ }^{\dagger} p<0.05$ vs. CP + mesna, ${ }^{\ddagger} p<0.05$ vs. CP + EG $(50 \mathrm{mg} / \mathrm{kg})$. Statistical analysis was done using one-way ANOVA followed by Tukey's multiple comparisons test. NC: normal control, CP: cyclophosphamide, EG: E. globulus.

\section{Discussion}

In this study, the hepato-renal protective activities of EG were examined in CP treated mice. Results were compared to the uroprotective thiol "mesna", which is routinely prescribed as an adjuvant treatment regimen to reduce the risk of hemorrhagic cystitis [15].

In this study, CP treated mice revealed a prominent increase in serum levels of hepatoxicity biomarkers (ALT and AST) by approximately 3-fold, as previously described [17,49]. Hepatotoxicity is reported to be one of the major side effects of CP induced hepatic damage with increased permeability of cell membrane and leakage of liver enzymes, specifically ALT and AST [50]. EG did not only normalize the elevated levels of ALT and AST but also restored the normal hepatic architecture. In CP treated mice, impairment in kidney functions was expressed as increased leakage of creatinine and urea into the systemic circulation, glomerular degenerative changes, and atrophy in kidney tissues. The recorded steep reduction in the levels of creatinine and BUN accompanied with amelioration of the kidney degenerative changes in EG pretreated groups may point to a possible nephro-protective activity.

In the current study, the oxidative/antioxidative mechanisms were examined, since oxidative stress is well known to play a pivotal role in the pathogenesis of CP induced toxicity, which mainly results from its toxic metabolite acrolein [51]. Acrolein induces the generation of ROS leading to enhanced lipid peroxidation and reduction in the antioxidant defense system in liver and kidney tissues [14,52]. In agreement with previous studies [17,49], our data showed an exacerbation in ROS production as denoted by the significant increase in the final product of lipid peroxidation, MDA, in liver and kidney of CP treated mice. Moreover, a substantial depletion in hepatic and renal GSH contents (by $72 \%$ and $68 \%$, respectively) was observed. This could be attributed to the direct conjugation of $\mathrm{CP}$ and its metabolites (acrolein and phosphoramide mustard) to the free or protein-bound -SH groups of GSH [53], denoting declined cellular defenses [54]. Pretreatment with EG restored the deficient thiol store in hepatic and renal cells by promoting the de novo synthesis of GSH. Previous studies documented the free radical scavenging activities of EG in alloxan-induced oxidative stress [55] and acetaminophen-induced kidney damages in rats [56]. In this study HPLC-DAD-ESI-MS/MS analysis of EG leaf extract revealed the presence of polyphenols with flavonoids (luteolin, kampferol and iridin) and tannins (gallotannins and ellagitannins) as major constituents. Flavonoids [29,57] and tannins [58] are reported to exhibit powerful antioxidant and free radical scavenging effects.

$\mathrm{NO}$ is known to play an essential role in regulating cellular stress [59]. NO directly result from the up-regulated expression of inducible NO synthase (iNOS) indicating impaired cellular viability [60]. NO is apparently involved in CP induced toxicity $[59,61]$, this is in coherence with our findings where NO was significantly increased in both the hepatic and renal tissues of CP treated mice by almost 3-fold. Moreover, the detected increase in NO was accompanied with elevated liver and kidney PC contents in CP treated mice by almost 2-fold. PC content is a marker expressing the extent of protein damage [62,63], and its enhanced levels is indicative of DNA damage and mutation resulting from excessive production of ROS in liver [64] and kidney [65] tissues. EG pretreatment led to normalization of NO levels indicating hepato- and nephro-protection against CP induced oxidative stress. In addition, the reduced hepatic and renal PC contents may indicate significant recovery of DNA damage suggesting possible assistant role for EG in tissue regeneration.

In addition, we investigated the impact of EG pretreatment on the up-regulation of the Nrf2/HO-1/antioxidant signaling pathway, which is considered one of the key defense mechanisms against stress-associated injuries [66]. Under stress conditions, various stimuli as ROS and pro-inflammatory cytokines [67] adversely result in the down-regulation of Nrf2 expression in liver and kidney cells, thereby moderating the transcription of the cytoprotective isoenzyme heme 
oxygenase-1 (HO-1) [14,19]. In the current work, CP resulted in a significant down-regulation of the hepatic and renal Nrf2 gene expressions along with marked reduction in their HO-1 levels, which could be linked to the excessive production of ROS, as previously reported $[68,69]$. Notably, pretreatment with EG demonstrated an activation of Nrf2 gene expression complemented with subsequent elevation in HO-levels in both hepatic and renal tissues implying that the recorded EG antioxidant effects can be partly attributed to the up-regulation of the Nrf2/HO-1 antioxidant signaling pathway.

Additionally, the oxidative/nitrosative stress generated by $\mathrm{CP}$ is known to be associated with the subsequent activation of inflammatory cascades $[19,30]$. NF- $\kappa B$ is a redox-sensitive transcription factor that regulates the expression and activation of pro-inflammatory cytokines and other mediators of inflammation including IL-6, TNF- $\alpha$, and iNOS [70-72]. In the current study, CP-treatment elicited an increase in NF-kB IHC expression with marked elevation in levels of TNF- $\alpha$ and IL-6 in hepatic and renal tissues $[14,60]$. The increased NF-kB expression is known to trigger the expression of iNOS, which in turn causes the overproduction of $\mathrm{NO}$ [73], as reported herein. The recorded decrease in the hepatic and renal levels of the pro-inflammatory cytokines (TNF- $\alpha$ and IL-6), NO along with subsequent down-regulation in NF- $\mathrm{KB}$ expression in EG pretreated mice could be related to EG compensatory mechanism against the inflammatory milieu generated in CP treated mice. The anti-inflammatory activities of EG was previously demonstrated in inflammatory-mediated disorders [74].

$\mathrm{CP}$ induced oxidative/nitrosative stress and inflammatory responses are also known to trigger apoptotic cell death via both mitochondria-dependent and mitochondria-independent apoptotic pathways [75], leading to activation of the executioner apoptotic marker caspase-3 [76]. The IHC expression of caspase-3 was up-regulated in both hepatic and renal tissues of CP treated mice. Pretreatment with EG extract counteracted the CP-induced apoptotic changes as evidenced by the marked regression in caspase-3 positively stained cells. This observed anti-apoptotic effect of EG could be directly linked to its antioxidant and anti-inflammatory properties.

In this study, mesna demonstrated minor to moderate hepatoprotective and nephroprotective activities. EG showed better results in terms of dose dependent improvement in the assessed biochemical and imunohistopathological parameters upon the use of EG, especially when the dose of $100 \mathrm{mg} / \mathrm{kg}$ was applied. These findings are in agreement with US FDA report (2009) [15] stating the ineffectiveness of mesna in preventing or ameliorating other reported multi-organ toxicity elicited by CP. Our findings may be explained in the view of the pharmacokinetic profile of mesna, which is known to be distributed in the body in its biologically inactive disulfite form. It passes through the hepatic vasculature in an unchanged form [77] and undergoes reduction in the renal epithelial cells to the pharmacologically active thiol form, mesna, which is then excreted in urine and combines with acrolein to form the stable uro-nontoxic compounds via its sulfhydryl group [78].

\section{Conclusions}

HPLC-MS/MS profiling of the tannins-rich leaf extract of E. globulus resulted in characterization of 26 secondary metabolites including tannins, phenolic acids, and flavonoids. Moreover, our results revealed that alleviation of $\mathrm{CP}$-induced hepato/renal-toxicities can be related to the augmentation of antioxidant defenses at least partially through induction of $\mathrm{Nrf} / \mathrm{HO}-1$ signaling with attenuation of excessive inflammatory responses as well as apoptosis in the hepatic and renal tissues. EG may represent an effective and economic plant product that can protect against the risks of toxic CP activities. However, further investigations are required to examine the potential synergistic activity of EG on the chemotherapeutic efficacy of CP. Also, investigations are required in a clinical context to confirm its hepato- and nephro-protective activities.

Supplementary Materials: The following are available online at http://www.mdpi.com/2076-3921/8/9/415/s1. Annotation of the polyphenolic compounds using HPLC-DAD-ESI-MS/MS (S1) and structural elucidation of the isolated phenolic compounds (S2).

Author Contributions: M.A.G., performed the extraction, participated in the chemical characterization of the extract, participated in the structural elucidation of the isolated compounds, analyzed the data, wrote \& revised 
the paper, conceived and designed the project; M.S., participated in the chemical identification of the extract and wrote the paper; W.H.E.-M., shared in the design of work, conducted the animal study and biochemical investigations, interpretation of obtained data, statistical analysis, shared in original draft preparation, graphical abstract design as well as sharing in reviewing and editing of the submitted version of the manuscript; H.S.M., performed the chromatographic isolation, participated in the identification of the compounds and wrote the paper.; H.K., conducted the histopathological and immunohistochemical examinations; S.B., wrote \& revised the paper and conceived the study; M.W., revised the paper and conceived the study.

Funding: The authors received financial support from the Deutsche Forschungsgemeinschaft and Ruprecht-KarlsUniversität Heidelberg within the funding program Open Access Publishing.

Acknowledgments: The authors would like to thank Dr. Tearse Labib, Botany Specialist, Department of Flora and Taxonomy, El-Orman Botanical Garden, Giza, Egypt, for her kind identification of the plant.

Conflicts of Interest: The authors declare no conflict of interest.

\section{Abbreviations}

HPLC-DAD-ESI-MS/MS

EG

$\mathrm{CP}$

NF-KB

$\mathrm{PC}$

Nrf2

HO-1

(IL)-6

(TNF)- $\alpha$

ROS

Mesna

DMSO

PBS

DME

PC

UV

CC

BIW

i.p.

ALT

AST

BUN

qRT-PCR

$H \& E$

MDA

iNOS

US FDA

$\mathrm{NO}$
High performance liquid chromatography coupled with diode array detection $(D A D)$ and electrospray mass spectrometry (MS)

Eucalyptus globulus

Cyclophosphamide

Nuclear factor kappa-B

Protein carbonylation

Nuclear factor E2-related factor 2

Hemoxygenase-1

Interleukin

Tumor necrosis factor

Reactive oxygen species

(2-mercaptoethane sulphonic acid)

Dimethyl sulfoxide

Phosphate buffered saline

Defatted methanol extract

Paper chromatography

Ultra-violet

Column chromatography

Butanol: isopropanol: water

Intraperitoneally

Alanine transaminase

Aspartate transaminase

Blood urea nitrogen

Quantitative reverse transcriptase real time polymerase chain reaction

Hematoxylin/eosin

Malondialdehyde

Inducible nitric oxide synthase

United States Food and Drug Administration

Nitric oxide

\section{References}

1. Rehman, M.U.; Tahir, M.; Ali, F.; Qamar, W.; Lateef, A.; Khan, R.; Quaiyoom, A.; Oday-O-Hamiza; Sultana, S. Cyclophosphamide-induced nephrotoxicity, genotoxicity, and damage in kidney genomic DNA of Swiss albino mice: The protective effect of ellagic acid. Mol. Cell. Biochem. 2012, 365, 119-127. [CrossRef] [PubMed]

2. Cuce, G.; Çetinkaya, S.; Koc, T.; Esen, H.H.; Limandal, C.; Balci, T.; Kalkan, S.; Akoz, M. Chemoprotective effect of vitamin $\mathrm{E}$ in cyclophosphamide induced hepatotoxicity in rats. Chem. Biol. Interact. 2015, 232, 7-11. [CrossRef] [PubMed]

3. Basu, A.; Bhattacharjee, A.; Samanta, A.; Bhattacharya, S. Prevention of cyclophosphamide-induced hepatotoxicity and genotoxicity: Effect of an l-cysteine based oxovanadium (IV) complex on oxidative stress and DNA damage. Environ. Toxicol. Pharm. 2015, 40, 747-757. [CrossRef] [PubMed] 
4. Bhattacharjee, A.; Basu, A.; Biswas, J.; Bhattacharya, S. Nano-Se attenuates cyclophosphamide-induced pulmonary injury through modulation of oxidative stress and DNA damage in Swiss albino mice. Mol. Cell. Biochem. 2015, 405, 243-256. [CrossRef] [PubMed]

5. Hamsa, T.P.; Kuttan, G. Protective role of Ipomoea obscura (L.) on cyclophosphamide-induced uro- and nephrotoxicities by modulating antioxidant status and pro-inflammatory cytokine levels. Inflammopharmacology 2011, 19, 155-167. [CrossRef] [PubMed]

6. Jiang, W.; Liu, J.; Li, P.; Lu, Q.; Pei, X.; Sun, Y.; Wang, G.; Hao, K. Magnesium isoglycyrrhizinate shows hepatoprotective effects in a cyclophosphamide-induced model of hepatic injury. Oncotarget 2017, 8, 33252-33264. [CrossRef]

7. Zarei, M.; Shivanandappa, T. Amelioration of cyclophosphamide-induced hepatotoxicity by the root extract of Decalepis hamiltonii in mice. Food Chem. Toxicol. 2013, 57, 179-184. [CrossRef]

8. Olayinka, E.; Ore, A.; Ola, O.; Adeyemo, O.A. Ameliorative effect of gallic acid on cyclophosphamide-induced oxidative injury and hepatic dysfunction in rats. Med. Sci. 2015, 3, 78-92. [CrossRef]

9. Gunes, S.; Ayhanci, A.; Sahinturk, V.; Altay, D.U.; Uyar, R. Carvacrol attenuates cyclophosphamide-induced oxidative stress in rat kidney. Can. J. Physiol. Pharm. 2017, 95, 844-849. [CrossRef]

10. Shokrzadeh, M.; Ahmadi, A.; Naghshvar, F.; Chabra, A.; Jafarinejhad, M. Prophylactic efficacy of melatonin on cyclophosphamide-induced liver toxicity in mice. BioMed Res. Int. 2014, 2014, 470425. [CrossRef]

11. Negre-Salvayre, A.; Auge, N.; Ayala, V.; Basaga, H.; Boada, J.; Brenke, R.; Chapple, S.; Cohen, G.; Feher, J.; Grune, T.; et al. Pathological aspects of lipid peroxidation. Free Radic. Res. 2010, 44, 1125-1171. [CrossRef] [PubMed]

12. Kiuchi, H.; Takao, T.; Yamamoto, K.; Nakayama, J.; Miyagawa, Y.; Tsujimura, A.; Nonomura, N.; Okuyama, A. Sesquiterpene lactone parthenolide ameliorates bladder inflammation and bladder overactivity in cyclophosphamide induced rat cystitis model by inhibiting nuclear factor-kappaB phosphorylation. J. Urol. 2009, 181, 2339-2348. [CrossRef] [PubMed]

13. Lin, S.; Hao, G.; Long, M.; Lai, F.; Li, Q.; Xiong, Y.; Tian, Y.; Lai, D. Oyster (Ostrea plicatula Gmelin) polysaccharides intervention ameliorates cyclophosphamide-Induced genotoxicity and hepatotoxicity in mice via the Nrf2-ARE pathway. Biomed. Pharm. 2017, 95, 1067-1071. [CrossRef] [PubMed]

14. ALHaithloul, H.A.S.; Alotaibi, M.F.; Bin-Jumah, M.; Elgebaly, H.; Mahmoud, A.M. Olea europaea leaf extract up-regulates Nrf2/ARE/HO-1 signaling and attenuates cyclophosphamide-induced oxidative stress, inflammation and apoptosis in rat kidney. Biomed. Pharm. 2019, 111, 676-685. [CrossRef] [PubMed]

15. US Food and Drug Administration (2009). Available online: https://www.accessdata.fda.gov/drugsatfda docs/nda/2002/20-855_Mesnex_Prntlbl.pdf (accessed on 29 July 2017).

16. Yilmaz, N.; Emmungil, H.; Gucenmez, S.; Ozen, G.; Yildiz, F.; Balkarli, A.; Kimyon, G.; Coskun, B.N.; Dogan, I.; Pamuk, O.N.; et al. Incidence of cyclophosphamide-induced urotoxicity and protective effect of Mesna in rheumatic diseases. J. Rheumatol. 2015, 42, 1661-1666. [CrossRef] [PubMed]

17. Caglayan, C.; Temel, Y.; Kandemir, F.M.; Yildirim, S.; Kucukler, S. Naringin protects against cyclophosphamide-induced hepatotoxicity and nephrotoxicity through modulation of oxidative stress, inflammation, apoptosis, autophagy, and DNA damage. Envrion. Sci. Pollut. Res. Int. 2018, 25, 20968-20984. [CrossRef] [PubMed]

18. Cerig, S.; Geyikoglu, F.; Bakir, M.; Colak, S.; Sonmez, M.; Koc, K. Hepatoprotective effect of oleuropein against cisplatin-induced liver damage in rat. World Acad. Sci. Eng. Technol. 2016, 10, 260-267. [CrossRef]

19. Sherif, I.O. The effect of natural antioxidants in cyclophosphamide-induced hepatotoxicity: Role of Nrf2/HO-1 pathway. Int. Immunopharmacol. 2018, 61, 29-36. [CrossRef]

20. Murali, V.P.; Kuttan, G. Enhancement of cancer chemotherapeutic efficacy of cyclophosphamide by Curculigo orchioides Gaertn and its ameliorative effects on cyclophosphamide-induced oxidative stress. Integr. Cancer Ther. 2015, 14, 172-183. [CrossRef]

21. White, D.A.; McGrath, J.F.; Ryan, M.G.; Battaglia, M.; Mendham, D.S.; Kinal, J.; Downes, G.M.; Crombie, D.S.; Hunt, M.E. Managing for water-use efficient wood production in Eucalyptus globulus plantations. For. Ecol. Manag. 2014, 331, 272-280. [CrossRef]

22. Nakhaee, A.; Bokaeian, M.; Saravani, M.; Farhangi, A.; Akbarzadeh, A. Attenuation of oxidative stress in streptozotocin-induced diabetic rats by Eucalyptus globulus. Indian J. Clin. Biochem. 2009, 24, 419-425. [CrossRef] [PubMed] 
23. Al-Fatimi, M.; Friedrich, U.; Jenett-Siems, K. Cytotoxicity of plants used in traditional medicine in Yemen. Fitoterapia 2005, 76, 355-358. [CrossRef] [PubMed]

24. Vuong, Q.V.; Chalmers, A.C.; Bhuyan, D.J.; Bowyer, M.C.; Scarlett, C.J. Botanical, phytochemical, and anticancer properties of the Eucalyptus species. Chem. Biodivers. 2015, 12, 907-924. [CrossRef] [PubMed]

25. Islam, F.; Khatun, H.; Ghosh, S.; Ali, M.M.; Khanam, J.A. Bioassay of Eucalyptus extracts for anticancer activity against Ehrlich ascites carcinoma (eac) cells in Swiss albino mice. Asian Pac. J. Trop. Biomed. 2012, 2, 394-398. [CrossRef]

26. Islam, F.; Khatun, H.; Khatun, M.; Ali, S.M.; Khanam, J.A. Growth inhibition and apoptosis of Ehrlich ascites carcinoma cells by the methanol extract of Eucalyptus camaldulensis. Pharm. Biol. 2014, 52, 281-290. [CrossRef] [PubMed]

27. Boulekbache-Makhlouf, L.; Meudec, E.; Mazauric, J.P.; Madani, K.; Cheynier, V. Qualitative and semi-quantitative analysis of phenolics in Eucalyptus globulus leaves by high-performance liquid chromatography coupled with diode array detection and electrospray ionisation mass spectrometry. Phytochem. Anal. 2013, 24, 162-170. [CrossRef]

28. Dezsi, S..; Bădărău, A.S.; Bischin, C.; Vodnar, D.C.; Silaghi-Dumitrescu, R.; Gheldiu, A.M.; Mocan, A.; Vlase, L. Antimicrobial and antioxidant activities and phenolic profile of Eucalyptus globulus Labill. and Corymbia ficifolia (F. Muell.) K.D. Hill \& L.A.S. Johnson leaves. Molecules 2015, 20, 4720-4734. [CrossRef] [PubMed]

29. Ghareeb, M.A.; Mohamed, T.; Saad, A.M.; Refahy, L.A.; Sobeh, M.; Wink, M. HPLC-DAD-ESI-MS/MS analysis of fruits from Firmiana simplex (L.) and evaluation of their antioxidant and antigenotoxic properties. J. Pharm. Pharm. 2018, 70, 133-142. [CrossRef] [PubMed]

30. Sharma, S.; Sharma, P.; Kulurkar, P.; Singh, D.; Kumar, D.; Patial, V. Iridoid glycosides fraction from Picrorhiza kurroa attenuates cyclophosphamide-induced renal toxicity and peripheral neuropathy via PPAR- $\gamma$ mediated inhibition of inflammation and apoptosis. Phytomedicine 2017, 36, 108-117. [CrossRef]

31. Abdi, S.A.; Najmi, A.K.; Raisuddin, S. Cyclophosphamide-induced down-regulation of uroplakin II in the mouse urinary bladder epithelium is prevented by S-allyl cysteine. Basic Clin. Pharm. Toxicol. 2016, 119, 598-603. [CrossRef]

32. Ellman, G.L. Tissue sulfhydryl groups. Arch. Biochem. Biophys. 1959, 82, 70-77. [CrossRef]

33. Ohkawa, H.; Ohishi, N.; Yagi, K. Assay for lipid peroxides in animal tissues by thiobarbituric acid reaction. Anal. Biochem. 1979, 95, 351-358. [CrossRef]

34. Wyrepkowski, C.C.; da Costa, D.M.G.; Sinhorin, A.P.; Vilegas, W.; De Grandis, R.A.; Resende, F.A.; Varanda, E.A.; dos Santos, L.C. Characterization and quantification of the compounds of the ethanolic extract from Caesalpinia ferrea stem bark and evaluation of their mutagenic activity. Molecules 2014, 19, 16039-16057. [CrossRef] [PubMed]

35. Abu-Reidah, I.M.; Ali-Shtayeh, M.S.; Jamous, R.M.; Arráez-Román, D.; Segura-Carretero, A. HPLC-DAD-ESIMS/MS screening of bioactive components from Rhus coriaria L. (Sumac) fruits. Food Chem. 2015, 166, 179-191. [CrossRef] [PubMed]

36. Dueñas, M.; Mingo-Chornet, H.; Pérez-Alonso, J.J.; Paola-Naranjo, R.D.; González-Paramás, A.M.; Santos-Buelga, C. Preparation of quercetin glucuronides and characterization by HPLC-DAD-ESI/MS. Eur. Food Res. Technol. 2008, 227, 1069-1076. [CrossRef]

37. Bhat, G.; Shawl, A.S.; Shah, Z.; Tantry, M. HPLC-DAD-ESI-MS/MS identification and characterization of major constituents of Iris crocea, Iris germanica and Iris spuria growing in Kashmir Himalayas, India. J. Anal. Bioanal. Tech. 2014, 5, 223. [CrossRef]

38. Ghareeb, M.; Saad, A.; Ahmed, W.; Refahy, L.; Nasr, S. HPLCDAD-ESI-MS/MS characterization of bioactive secondary metabolites from Strelitzia nicolai leaf extracts and their antioxidant and anticancer activities In vitro. Phcog. Res. 2018, 10, 368-378. [CrossRef]

39. Gordon, A.; Jungfer, E.; da Silva, B.A.; Maia, J.G.S.; Marx, F. Phenolic constituents and antioxidant capacity of four underutilized fruits from the amazon region. J. Agric. Food Chem. 2011, 59, 7688-7699. [CrossRef]

40. Matsunami, K.; Takamor, I.; Shinzato, T. Radical-scavenging activities of new megastigmane glucosides from Macaranga tanarius (L.) MULL.-ARG. Chem. Pharm. Bull. 2006, 54, 1403-1407. [CrossRef]

41. Boulekbache-Makhlouf, L.; Meudec, E.; Chibane, M.; Mazauric, J.P.; Cheynier, V.; Slimani, S.; Henry, M.; Madani, K. Analysis of phenolic compounds in fruit of Eucalyptus globulus cultivated in Algeria by high-performance liquid chromatography diode array detection mass spectrometry. J. Agric. Food Chem. 2010, 58, 12615-12624. [CrossRef] 
42. Singab, A.; Ayoub, N.; Al-Sayed, E.; Martiskainen, O.; Sinkkonen, J.; Pihlaja, K. Phenolic constituents of Eucalyptus camaldulensis Dehnh, with potential antioxidant and cytotoxic activities. Rec. Nat. Prod. 2011, 5, 271-280.

43. Sandhu, A.K.; Gu, L. Antioxidant capacity, phenolic content, and profiling of phenolic compounds in the

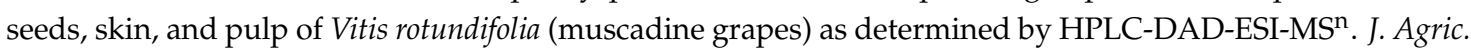
Food Chem. 2010, 58, 4681-4692. [CrossRef] [PubMed]

44. Chen, X.; Bergmeier, S. Compositions of glucose transport inhibitors as antitumor agents. International PCT Patent WO 2011119866 A1 20110929, 29 September 2011.

45. Schuster, B.; Winter, M.; Herrmann, K. 4-O- $\beta$-D-glucosides of hydroxybenzoic and hydroxycinnamic acids-their synthesis and determination in berry fruit and vegetable. Z. Naturforsch. 1986, 41, 511-520. [CrossRef]

46. Eldahshan, O.A. Isolation and structure elucidation of phenolic compounds of Carob leaves grown in Egypt. Curr. Res. J. Biol. Sci. 2011, 3, 52-55.

47. Ekaprasada, M.T.; Nurdin, H.; Ibrahim, S.; Hamidi, D. Antioxidant activity of methyl gallate isolated from the leaves of Toonasureni. Indones. J. Chem. 2009, 9, 457-460. [CrossRef]

48. Choi, J.G.; Mun, S.H.; Chahar, H.S.; Bharaj, P.; Kang, O.H.; Kim, S.G.; Shin, D.W.; Kwon, D.Y. Methyl Gallate from Galla rhois successfully controls clinical isolates of Salmonella infection in both in vitro and in vivo systems. PLoS ONE 2014, 9, e102697. [CrossRef]

49. Mansour, D.F.; Salama, A.A.A.; Hegazy, R.R.; Omara, E.A.; Nada, S.A. Whey protein isolate protects against cyclophosphamide-induced acute liver and kidney damage in rats. J. Appl. Pharm. Sci. 2017, 7, 111-120. [CrossRef]

50. Kamel, E.M.; Mahmoud, A.M.; Ahmed, S.A.; Lamsabhi, A.M. A phytochemical and computational study on flavonoids isolated from Trifolium resupinatum L. and their novel hepatoprotective activity. Food Funct. 2016, 7, 2094-2106. [CrossRef]

51. Zhu, H.; Long, M.H.; Wu, J.; Wang, M.M.; Li, X.Y.; Shen, H.; Xu, J.D.; Zhou, L.; Fang, Z.J.; Luo, Y.; et al. Ginseng alleviates cyclophosphamide-induced hepatotoxicity via reversing disordered homeostasis of glutathione and bile acid. Sci. Rep. 2015, 5, 17536. [CrossRef]

52. Mahmoud, A.M.; Germoush, M.O.; Alotaibi, M.F.; Hussein, O.E. Possible involvement of Nrf2 and PPAR $\gamma$ up-regulation in the protective effect of umbelliferone against cyclophosphamide-induced hepatotoxicity. Biomed. Pharm. 2017, 86, 297-306. [CrossRef]

53. Yousefipour, Z.; Ranganna, K.; Newaz, M.A.; Milton, S.G. Mechanism of acrolein-induced vascular toxicity. J. Physiol. Pharmacol. 2005, 56, 337-353. [PubMed]

54. Srivastava, A.; Shivanandappa, T. Hepatoprotective effect of the root extract of Decalepis hamiltonii against carbon tetrachloride-induced oxidative stress in rats. Food Chem. 2010, 118, 411-417. [CrossRef]

55. Ahlem, S.; Khaled, H.; Wafa, M.; Sofiane, B.; Mohamed, D.; Jean-Claude, M.; Abdelfattah, E.F. Oral administration of Eucalyptus globulus extract reduces the alloxan-induced oxidative stress in rats. Chem. Biol. Interact. 2009, 181, 71-76. [CrossRef] [PubMed]

56. Dhibi, S.; Mbarki, S.; Elfeki, A.; Hfaiedh, N. Eucalyptus globulus extract protects upon acetaminophen-induced kidney damages in male rat. Bosn. J. Basic Med. Sci. 2014, 14, 99-104. [CrossRef] [PubMed]

57. Ghareeb, M.A.; Sobeh, M.; Rezq, S.; El-Shazly, A.M.; Mahmoud, M.F.; Wink, M. HPLC-ESI-MS/MS profiling of polyphenolics of a leaf extract from Alpinia zerumbet (Zingiberaceae) and its anti-inflammatory, anti-nociceptive, and antipyretic activities in vivo. Molecules 2018, 23, 3238. [CrossRef] [PubMed]

58. Sobeh, M.; Mahmoud, M.F.; Hasan, R.A.; Abdelfattah, M.A.O.; Sabry, O.M.; Ghareeb, M.A.; El-Shazly, A.M.; Wink, M. Tannin-rich extracts from Lannea stuhlmannii and Lannea humilis (Anacardiaceae) exhibit hepatoprotective activities in vivo via enhancement of the anti-apoptotic protein Bcl-2. Sci. Rep. 2018, 8, 9343. [CrossRef] [PubMed]

59. Goligorsky, M.S.; Brodsky, S.V.; Noiri, E. Nitric oxide in acute renal failure: NOS versus NOS. Kidney Int. 2002, 61, 855-861. [CrossRef]

60. Mahmoud, A.M.; Al Dera, H.S. 18ß-Glycyrrhetinic acid exerts protective effects against cyclophosphamideinduced hepatotoxicity: Potential role of PPAR $\gamma$ and Nrf2 upregulation. Genes Nutr. 2015, 10, 41. [CrossRef]

61. Andersson, M.C.; Tobin, G.; Giglio, D. Cholinergic nitric oxide release from the urinary bladder mucosa in cyclophosphamide-induced cystitis of the anaesthetized rat. Br. J. Pharm. 2008, 153, 1438-1444. [CrossRef] 
62. Tokyay, R.; Kaya, E.; Gur, E.; Tuncel, P.; Ozbek, R.; Ozturk, E. Prostaglandin synthetase inhibition reduces peritonitis-induced early liver oxidant stress. Surg. Today 1999, 29, 42-46. [CrossRef]

63. Dalle-Donne, I.; Rossi, R.; Giustarini, D.; Milzani, A.; Colombo, R. Protein carbonyl groups as biomarkers of oxidative stress. Clin. Chim. Acta 2003, 329, 23-38. [CrossRef]

64. Laamech, J.; El-Hilaly, J.; Fetoui, H.; Chtourou, Y.; Gouitaa, H.; Tahraoui, A.; Lyoussi, B. Berberis vulgaris L. effects on oxidative stress and liver injury in lead-intoxicated mice. J. Complement. Integr. Med. 2017, 14, 20150079. [CrossRef] [PubMed]

65. Quirós, Y.; Blanco-Gozalo, V.; Sanchez-Gallego, J.I.; López-Hernandez, F.J.; Ruiz, J.; Perez de Obanos, M.P.; López-Novoa, J.M. Cardiotrophin-1 therapy prevents gentamicin-induced nephrotoxicity in rats. Pharm. Res. 2016, 107, 137-146. [CrossRef] [PubMed]

66. Panchal, S.K.; Poudyal, H.; Brown, L. Quercetin ameliorates cardiovascular, hepatic, and metabolic changes in diet-induced metabolic syndrome in rats. J. Nutr. 2012, 142, 1026-1032. [CrossRef] [PubMed]

67. Bryan, H.K.; Olayanju, A.; Goldring, C.E.; Park, B.K. The Nrf2 cell defence pathway: Keap1-dependent and -independent mechanisms of regulation. Biochem. Pharm. 2013, 85, 705-717. [CrossRef] [PubMed]

68. Abd El-Twab, S.M.; Hozayen, W.G.; Hussein, O.E.; Mahmoud, A.M. 18ß-Glycyrrhetinic acid protects against methotrexate-induced kidney injury by up-regulating the Nrf2/ARE/HO-1 pathway and endogenous antioxidants. Ren. Fail. 2016, 38, 1516-1527. [CrossRef] [PubMed]

69. Wu, T.; Li, J.; Li, Y.; Song, H. Antioxidant and hepatoprotective effect of swertiamarin on carbon tetrachloride-induced hepatotoxicity via the Nrf2/HO-1 pathway. Cell. Physiol. Biochem. 2017, 41, 2242-2254. [CrossRef] [PubMed]

70. Farombi, E.O.; Shrotriya, S.; Surh, Y.J. Kolaviron inhibits dimethyl nitrosamine-induced liver injury by suppressing COX-2 and iNOS expression via NF-кB and AP-1. Life Sci. 2009, 84, 149-155. [CrossRef]

71. Nafees, S.; Rashid, S.; Ali, N.; Hasan, S.K.; Sultana, S. Rutin ameliorates cyclophosphamide induced oxidative stress and inflammation in Wistar rats: Role of NFKB/MAPK pathway. Chem. Biol. Interact. 2015, 231, 98-107. [CrossRef]

72. Kandemir, F.M.; Kucukler, S.; Caglayan, C.; Gur, C.; Batil, A.A.; Gülçin, İ. Therapeutic effects of silymarin and naringin on methotrexate-induced nephrotoxicity in rats: Biochemical evaluation of anti-inflammatory, antiapoptotic, and antiautophagic properties. J. Food Biochem. 2017, 41, e12398. [CrossRef]

73. El-Kholy, A.A.; Elkablawy, M.A.; El-Agamy, D.S. Lutein mitigates cyclophosphamide induced lung and liver injury via NF-кB/MAPK dependent mechanism. Biomed. Pharm. 2017, 92, 519-527. [CrossRef] [PubMed]

74. Ji, Y.E.; Sun, X.; Kim, M.K.; Li, W.Y.; Lee, S.W.; Koppula, S.; Yu, S.H.; Kim, H.B.; Kang, T.B.; Lee, K.H. Eucalyptus globulus inhibits inflammasome-activated pro-inflammatory responses and ameliorate monosodium urate-induced peritonitis in murine experimental model. Am. J. Chin. Med. 2018, 46, 423-433. [CrossRef] [PubMed]

75. Sinha, K.; Das, J.; Pal, P.B.; Sil, P.C. Oxidative stress: The mitochondria-dependent and mitochondriaindependent pathways of apoptosis. Arch. Toxicol. 2013, 87, 1157-1180. [CrossRef] [PubMed]

76. Tsamandas, A.C.; Thomopoulos, K.; Zolota, V.; Kourelis, T.; Karatzas, T.; Ravazoula, P.; Tepetes, K.; Petsas, T.; Karavias, D.; Karatza, C.; et al. Potential role of bcl-2 and bax mRNA and protein expression in chronic hepatitis type B and C: A clinicopathologic study. Mod. Pathol. 2003, 16, 1273-1288. [CrossRef] [PubMed]

77. Brock, N.; Pohl, J. Prevention of urotoxic side effects by regional detoxification with increased selectivity of oxazaphosphorine cytostatics. IARC Sci. Publ. 1986, 78, 269-279.

78. Hensley, M.L.; Schuchter, L.M.; Lindley, C.; Meropol, N.J.; Cohen, G.I.; Broder, G.; Gradishar, W.J.; Green, D.M.; Langdon, R.J., Jr.; Mitchell, R.B.; et al. American Society of Clinical Oncology clinical practice guidelines for the use of chemotherapy and radiotherapy protectants. J. Clin. Oncol. 1999, 17, 3333-3355. [CrossRef]

(C) 2019 by the authors. Licensee MDPI, Basel, Switzerland. This article is an open access article distributed under the terms and conditions of the Creative Commons Attribution (CC BY) license (http://creativecommons.org/licenses/by/4.0/). 